\title{
克隆乔木黄牛奶树枝条的功能特征
}

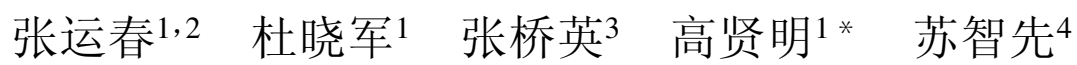

（1 中国科学院植物研究所植被数量生态学重点实验室, 北京 100093）

（2 山东轻工业学院, 济南 250100）（3 中国科学院成都生物研究所, 成都 610041）（4 绵阳师范学院, 四川绵阳 621000）

\begin{abstract}
摘 要 黄牛奶树 (Symplocos laurina) 是一种乔木克隆植物, 其枝担负着支撑叶进行光合作用和克隆苗繁殖两种功 能。由于枝功能的特异性在形态上表现出独特的特征: 上部的枝生长比较旺盛, 主要进行光合作用负责整个植株 的碳水化合物供应与积累;下部的枝在形态上有所变化, 基部细长而端部较基部明显增粗, 并下垂呈“ $V$ ” 状, 在生长 过程中增长明显而无明显增粗现象, 主要进行克隆繁殖。黄牛奶树的枝在由营养功能转变为繁殖功能的过程中年 萌发次数显著增加; 枝分化成克隆苗后在截取光能方面采取了不同的策略: 克隆苗作为一个新的生命体, 主要通过 增加叶量占据更大的水平空间来增大总叶面积以截取更多阳光, 不同于营养枝通过增加单叶面积占据更大的垂直 空间来增大总叶面积以截取更多阳光的方式,但在不同的生境下对照枝与压枝克隆苗达到的总叶面积却无显著差 异; 从各构件的生物量特征看, 对照枝的生物量主要分配在叶和叶柄等光合构件上, 而枝分化成克隆苗后生物量主 要分配在茎上。即黄牛奶树的枝随着着地后功能的变化, 在形态等各方面都有相应的变化, 这可能是由于功能变 化后内源激素发生变化的结果, 但这有待于进一步研究。
\end{abstract}

关键词 黄牛奶树 克隆繁殖 构件 生物量 可塑性

\section{FUNCTIONS OF BRANCHES OF THE CLONAL TREE SYMPLOCOS LAURINA}

\author{
ZHANG Yun-Chun ${ }^{1,2}$ DU Xiao-Jun ${ }^{1}$ ZHANG Qiao-Ying ${ }^{3} \quad$ GAO Xian-Ming ${ }^{*}{ }^{*}$ and SU Zhi-Xian ${ }^{4}$ \\ (1 Laboratory of Quantitative Vegetation Ecology, Institute of Botany, Chinese Academy of Sciences, Beijing 100093, China) \\ (2 Shandong Institute of Light Industry, Jinan 250100, China) （3 Chengdu Institute of Biology, Chengdu 610041, China) \\ (4 Mianyang Normal University, Mianyang, Sichuan 621000, China)
}

\begin{abstract}
Symplocos laurina is an arboreal clonal plant. Its branches are bi-functional organs that both undertake photosynthesis and produce ramets for propagation. Due to their unique functions, the branches of $S$. laurina differ in their physical appearance: upper branches grow well and rather strong and function to accumulate and provide photosynthates to the whole plant, whereas the lower branches have slim proximal ends but much sturdier head ends and grow downward in a $\mathrm{V}$ shape. Lower branches grow in length rather than in diameter to clone younger ramets. When branches switch their roles from photosynthetic structures to ramet producers, they experience much greater germination. Apical dominance and stimulation from root appearance may be the two primary reasons. Germination times are very different between ramets in different habitats but do not differ in control branches indicating that older and stronger trees are not as sensitive as the younger tender ramets to environmental conditions, even though the ramets are still connected to the mother plant. As new organisms, young ramets adopt different strategies to compete for light: they grow hard to increase the number of leaves so as to enlarge the total light-receiving area in horizontal space. In contrast, parent branches increase the area of each leaf to get the largest possible leaf area in vertical space. Because the ramets can germinate more than once a year, they can produce more leaves than their parent branches, which can only germinate once and the number of leaves are predetermined by the buds. However, even in different habitats, no significant differences in total leaf area were observed between ramet-produced branches and control branches. The biomass of leaves, petioles and the total biomass of plant change greatly among habitats, but they don' $t$ change with the role switch of the branches as ramets producers. Stem biomass does not respond to different habitats but the role switch of branches does affect stem biomass. Control branches allocate their biomass mainly to photosynthesis modules, such as leaves and petioles; in contrast ramets focus most their biomass on stems. We conclude that branches change their function after they take root in the ground, which brings about correspon-
\end{abstract}

基金项目: 国家重点基础研究发展规划项目(2002CB111504, G2000046802)、中国科学院知识创新工程项目 (KSCX-07-01-02)和国家自然科 学基金项目(39770134)

*通讯作者 Author for correspondence E-mail:xmgao@ibcas.ac.cn 
dent changes in their morphological features. This is probably due to internal hormonal changes as a branch changes its function but more research is needed to better understand this phenomenon.

Key words Clonal propagation, Module, Biomass, Plasticity

克隆植物的研究一直是植物生态学的热点。尤 其近年来, 对克隆植物种群生态学的研究方面取得 了很大的进展, 主要集中于以下几方面: 整合作用的 研究 (Alpert \& Mooney, 1986; Schmid, 1987; 王昱生和 李景信, 1992; 王昱生和盖晓春, 1995; Pitelka, 1985; Alpert, 1996; D’ Hertefeldt \& Jónsdóttir, 1999; 董鸣, 1996a，1996b); 可塑性的研究 (王昱生和盖晓春, 1995; Alpert, 1996; 董鸣, 1996a，1996b; 杨持和杨理, 1997; 陈劲松等, 2003); 克隆生长模型的研究 (Cain, 1990; de Kroon \& Schieving, 1991; Millette, 1992; 陈尚 等,1997); 克隆植物生存优势的研究(蒋高明和董 鸣, 2000)。但目前国内外植物克隆研究的材料多为 草本或木质草本 (竹子) 及灌木, 关于乔木克隆植物 及克隆植物繁殖体分化的研究少见报道。因此,对 乔木克隆植物的研究是揭示乔木克隆生长和生态适 应的基本内容。

黄牛奶树 (Symplocos laurina) 系山矾科山矾属的 一种常绿小乔木, 多分布于中低海拔地区林下。野 外调查发现, 四川省都江堰般若寺实验林场常绿阔 叶林内黄牛奶树数量较多, 且存在有性繁殖和克隆 繁殖两种繁殖方式, 对森林更新具重要意义, 但目前 有关黄牛奶树的研究极少, 尤其个体生态学的研究 尚未见报道。对黄牛奶树的研究可以揭示森林更新 中特殊种的具体作用。

枝是植物的重要组成部分之一, 是树冠组成的 基本单元, 也是植物进行光合作用制造养料的主要 构件。关于枝作为植物的构件的研究报道很多 （Fisher \& Honda, 1977; Harper, 1985; Alpert, 1996; 黎云 祥等, 1998; 张炜银等, 2002; 何丙辉和钟章成, 2003), 但对黄牛奶树的这种具有繁殖功能特殊枝的 研究国内外尚未见报道, 黄牛奶树的枝不同于大多 数乔木的枝,除具有一般乔木的枝的作用外, 还具有 克隆繁殖的作用, 承担繁殖功能的小枝能形成潜在 的独立个体一一无性系小株 (张运春等, 2001)。自 然条件下,生境条件的不同是导致种内差异的重要 原因。这种差异主要体现在无性繁殖和有性生殖两 方面(王仁忠, 2001)。对于黄牛奶树来说枝条分化 出克隆生殖枝就是对环境的一种适应。枝条的性别 分化一方面受其自身遗传特性的控制, 另一方面也 受环境条件的制约 (王仁忠, 2001)。不同生境下相
同的克隆植物或不同的克隆植物生殖枝和营养枝在 数量、形态和生理等方面都存在其特有的表现形式 (王仁忠, 2001; 黄䩀等, 2004; 郭力华等, 2004)。由 于功能的多样性, 黄牛奶树的枝在形态与生长和分 化等方面存在一些很独特的特征(张运春等, 2001), 本文就不同生境下黄牛奶树枝的这些特征进行了初 步的观察和实验, 并对同等条件下接触土壤的枝与 不接触土壤的枝进行了比较研究。探讨了不同生境 下营养枝与克隆苗的年生长次数、叶量、单叶面积、 总叶面积、叶生物量、叶柄生物量、径生物量和植株 生物量的差异及其原因, 旨在揭示乔木克隆过程中 繁殖体一一枝功能改变后其各部分的形态和生物量 的变化规律及适应对策。

\section{1 研究地区自然概况与研究方法}

\section{1 自然概况}

本研究在都江堰般若寺实验林场 (1033' $103^{\circ} 4^{\prime} \mathrm{E}, 31^{\circ} 41^{\prime} \sim 31^{\circ} 42^{\prime} \mathrm{N}$ ) 进行。海拔 $740 \mathrm{~m}$ 左右, 该区属中亚热带, 水热资源丰富, 年平均气温 $10{ }^{\circ} \mathrm{C}$ 左右, 1 月均温为 $6{ }^{\circ} \mathrm{C}, 7$ 月均温 $28.5{ }^{\circ} \mathrm{C}, \geqslant 10{ }^{\circ} \mathrm{C}$ 的 年积温 $4677.1{ }^{\circ} \mathrm{C}$ 。在这种温暖湿润的气候条件 下,地带性植被发育形成生物多样性丰富的常绿榈 叶林( 陈昌笃, 2000)。

根据植被类型设置了 4 块样地, 4 块样地相距 不远。样地 1 为慈竹 (Neosinocalamus affinis) 林, 主要 以慈竹为主, 其间有少量的黄牛奶树和青冈栋 ( $C y$ clobalanopsis glauca), 该样地土壤肥沃, 解放前曾为 耕地后改种慈竹; 样地 2 为慈竹与阔叶树混交林, 其 中慈竹、青冈栋、黄牛奶树、栲树 (Castanopsis fargesi$i$ )、短柄枹树 (Quercus serrata var. brevipeiolata) 和江 南石栋 (Lithocarpus harlandii) 均有分布; 样地 3 为常 绿阔叶林, 其中以栲树、江南石栎、青冈栋和黄牛奶 树为主, 栓皮栋 (Quercus variabilis)、灯台树 (Cornus controversa)、梓叶槭 ( Acer catalpifolium) 和楠木 (Phoebe zhennan) 有少量分布, 灌木层以海桐 ( Piuosporum daphniphylloides)、老鼠矢 (Symplocos stellaris)、 冬青( Ilex purpurea) 和铁仔 (Myrsine africana) 较多, 草 本层以柳叶箬 (Isachne globosa)、淡竹叶 (Lophantherum gracile) 和芒箕( Dicranopteris pedata) 为主; 样地 4 为针阔叶混交林, 乔木层主要以栓皮栋、栲树、青 
冈栋、江南石栋和马尾松 (Pinus massoniana) 为主, 灌 木层以油茶 (Camellia oleifera) 为优势种, 草本层仅有 零星分布, 以芒箕为主。

\section{2 材料}

黄牛奶树又称水冬瓜、冬桂树、泡花子; 常绿小 乔木, 高 4 12 m; 芽、幼枝、花序轴、苞片均被灰褐 色短柔毛; 叶革质, 卵形或狭椭圆形, 长 5 11 cm, 宽 $2 \sim 5 \mathrm{~cm}$, 顶端急尖或渐尖, 基部楔形或宽楔形, 边缘 有稀疏的针锯齿, 中脉在上面凹下; 穗状花序长 3 $6 \mathrm{~cm}$, 基部通常分枝; 苍片和小苞片边缘有腺点; 花 莕长约 $2 \mathrm{~mm}$, 无毛; 花冠长约 $4 \mathrm{~mm}$, 裂片长约 $3 \mathrm{~mm}$; 雄荵约 30 枚,花药基部合生成不显著的五体雄荵; 子房顶端无毛; 核果球形, 直径 $4 \sim 6 \mathrm{~mm}$, 顶端缢缩, 宿存萼片直立; 分布于华东、东南至西南各省区; 越 南、印度和斯里兰卡也有分布; 生于海拔 $1600 \mathrm{~m}$ 以 下的林中 (中国科学院植物研究所, 1974; 四川植物 志编辑委员会, 1981; 中国科学院中国植物志编辑委 员会, 1987)。

\section{3 实验方法和数据分析}

2000 年 12 月在都江堰般若寺实验林场选择慈 竹林 (样地 1)、慈竹与阔叶树混交林 (样地 2)、常绿 阔叶林(样地 3) 和针阔叶混交林 (样地 4) 4 个样地。 选择大小及年龄相近的黄牛奶树枝条 120 根 (每样 地 30 根, 15 根进行就地压枝使其形成克隆苗, 15 根 进行挂号标记保持其原状态不与土壤接触）。2001 年 12 月计测标记枝与克隆苗的年萌发次数和叶量 等指标, 并剪取标记枝与克隆苗植株, 用密封袋带回 室内用叶面积仪测叶面积及长宽等指标, 将植株分 为径、叶和叶柄后用电子天平 (精度为 $0.0001 \mathrm{~g}$ ) 称 量各构件的湿重和干重 $\left(105{ }^{\circ} \mathrm{C}\right.$ 杀青, $80{ }^{\circ} \mathrm{C}$ 烘干至恒 重)。用 SPSS10.0 软件包进行统计并运用 One-way ANOVA 对同一处理不同样地间的植株的年生长次 数、叶量、单叶面积、总叶面积、叶生物量、叶柄生物 量、径生物量、植株生物量及不同处理下相应指数间 差异的显著性进行方差分析。

\section{2 实验结果}

\section{1 黄牛奶树枝的分化特征}

通过长期的野外观察发现黄牛奶树上部的枝生 长比较旺盛, 主要进行光合作用负责整个植株的碳 水化合物供应与积累。而下部的枝在形态上, 基部 细长而端部较基部明显增粗, 并下垂呈“ $\mathrm{V}$ ” 状, 在生 长过程中其增长明显而无明显增粗。在雨季下垂部 位生出气生根一旦接触地面就会形成克隆苗, 如此
持续几年, 如一直不能接触地面此枝将慢慢枯死。

\section{2 植株的年萌发次数}

从对照枝与压枝形成的克隆苗的年萌发次数 (图 1, 表 1) 看, 各样地对照枝之间的年萌发次数差 异不显著, 各样地压枝形成的克隆苗之间的年萌发 次数有显著差异, 对照枝的年萌发次数 (4 个样地分 别为: $(1.00 \pm 0.00) 、(1.30 \pm 0.15) 、(1.11 \pm 0.11)$ 和 $(1.00 \pm 0.00))$ 与压枝形成的克隆苗的年萌发次数 (4 个样地分别为: $(1.43 \pm 0.14) 、(2.08 \pm 0.14)$ 、 $(1.91 \pm 0.091)$ 和 $(1.57 \pm 0.20))$ 差异极其显著 $(p<$ 0.01 ), 对照枝基本无二次生长, 而压枝形成的克隆 苗一般都有二次生长。从不同的样地来看, 虽然各 样地的水肥光照等条件不同, 但对照枝与压枝形成 的克隆苗的年萌发次数在各样地的变化规律基本一 致。

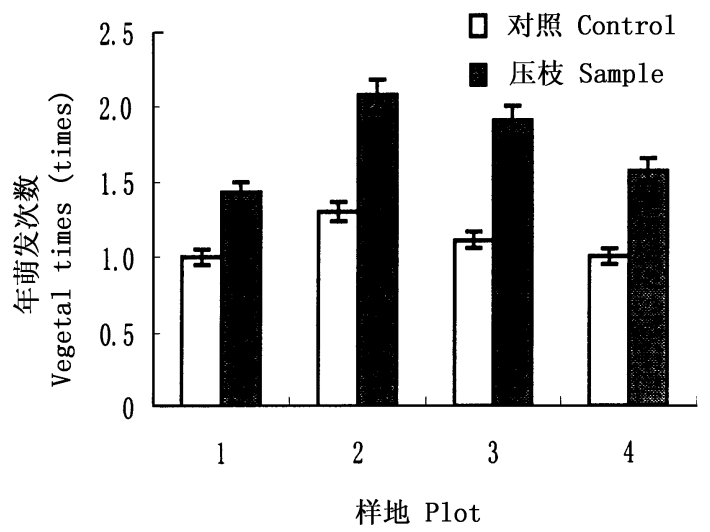

图 1 不同生境下对照枝与压枝的年萌发次数

Fig. 1 Vegetal times of clonal plant Symplocos laurina in different habitats

\section{3 植株的光合构件}

各样地对照枝之间的叶量差异不显著 $(p>$ $0.05)$, 各样地压枝克隆苗之间的叶量有极显著差异 $(p<0.01)$, 压枝克隆苗的叶量极显著大于对照枝的 叶量 $(p<0.01)$ 。各样地对照枝之间和压枝克隆苗 之间单叶面积均有极显著差异 $(p<0.01)$, 压枝克隆 苗的单叶面积极显著小于对照枝的单叶面积 $(p<$ 0.01)。各样地对照枝之间与压枝克隆苗之间的总 叶面积及压枝克隆苗与对照枝之间的总叶面积差异 均不显著 $(p>0.05)$ (图 2, 表 1)。

\section{4 植株的生物量特征}

各样地对照枝的叶生物量有极显著差异 ( $p<$ $0.01)$, 各样地压枝克隆苗的叶生物量有显著差异 $(p<0.05)$, 对照枝与压枝克隆苗的叶生物量差异不 显著 $(p>0.05)$; 各样地对照枝之间与压枝克隆苗之 
表 1 黄牛奶树植株特征的 One-way ANOVAs 的 $\boldsymbol{F}$ 值

Table 1 One-way ANOVAs analysis ( $F$-value) on the characters of clonal plant Symplocos laurina

\begin{tabular}{|c|c|c|c|}
\hline $\begin{array}{c}\text { 特征 } \\
\text { Characters }\end{array}$ & $\begin{array}{c}\text { 各样地的对照 } \\
\text { Controls in different habitats }\end{array}$ & $\begin{array}{c}\text { 各样地的压枝苗 } \\
\text { Samples in different habitats }\end{array}$ & $\begin{array}{c}\text { 对照与压枝 } \\
\text { Control and sample }\end{array}$ \\
\hline 年萌发次数 Vegetal times & 2.130 & $5.080^{*}$ & $42.883^{* *}$ \\
\hline 叶量 Number of leaves & 2.26 & $4.979^{* *}$ & $6.899^{* *}$ \\
\hline 单叶面积 Area of single leaf & $61.926^{* *}$ & $44.904^{* *}$ & $45.040^{* *}$ \\
\hline 总叶面积 Area of total leaves & 3.202 & 4.764 & 0.156 \\
\hline 叶生物量 Biomass of leaves & $9.427^{* *}$ & $5.798^{*}$ & 2.315 \\
\hline 叶柄生物量 Biomass of petioles & $6.839^{* *}$ & $8.695^{* *}$ & 3.926 \\
\hline 茎生物量 Biomass of stems & 3.053 & 3.053 & $14.432^{* *}$ \\
\hline 植株生物量 Biomass of whole plant & $8.338^{* *}$ & $4.829^{* *}$ & 0.4 \\
\hline 叶与生物量比 Ratio of leaves to biomass of whole plant & 1.008 & 2.723 & $64.274^{* *}$ \\
\hline 叶柄与生物量比 Ratio of petioles to biomass of whole plant & 0.140 & 2.647 & $44.721^{* *}$ \\
\hline 茎生物量比 Ratio of stems to biomass of whole plant & 0.903 & 2.829 & $68.522^{* *}$ \\
\hline
\end{tabular}
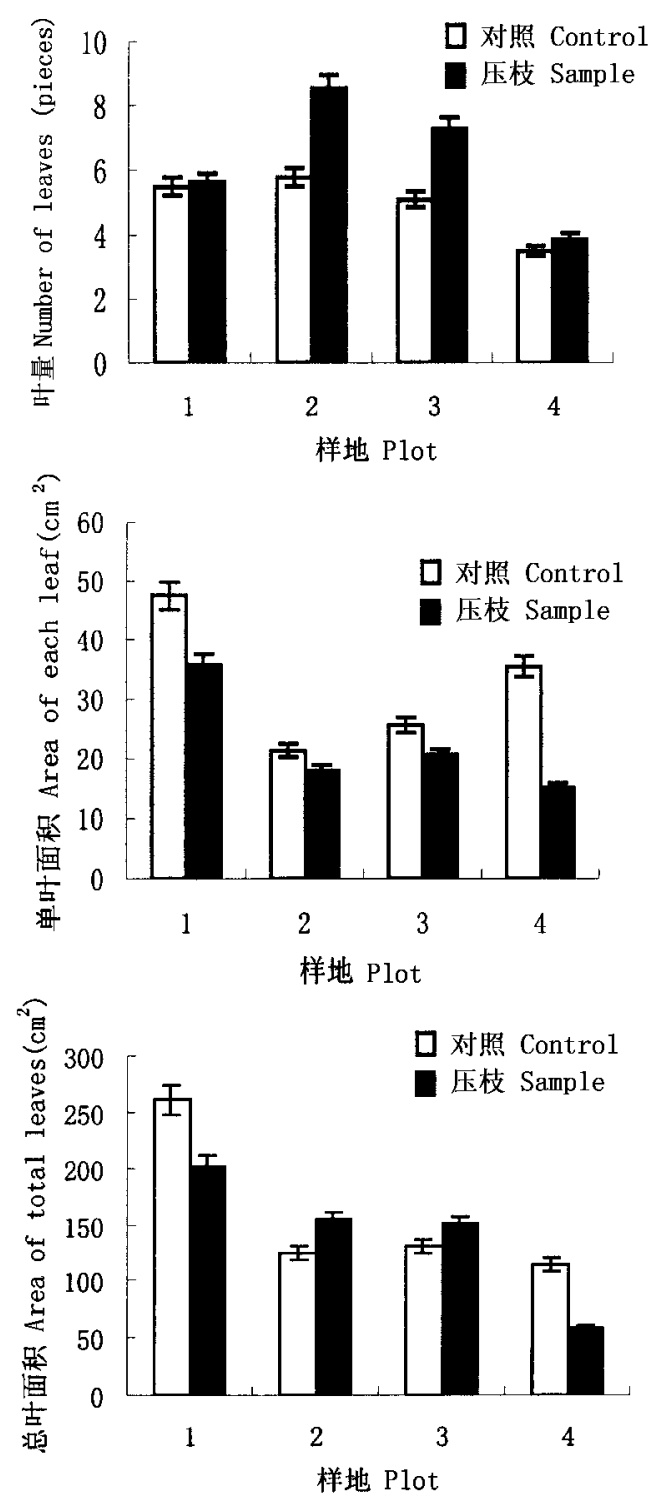

图 2 不同处理下植株的光合构件

Fig.2 Photosynthesis modules of clonal plant Symplocos laurina in different treatments
间的叶柄生物量差异均极显著 $(p<0.01)$, 对照枝与 压枝克隆苗叶柄生物量差异不显著 $(p>0.05)$; 各样 地对照枝之间和压枝克隆苗之间茎生物量差异均不 显著 $(p>0.05)$, 压枝克隆苗的茎生物量极显著大于 对照枝的茎生物量 $(p<0.01)$; 各样地对照枝之间和 压枝克隆苗之间植株生物量差异均极显著 $(p<$ $0.01)$, 对照枝与压枝克隆苗之间的植株生物量差异 不显著 $(p>0.05$ )(图 3, 表 1)。

\section{5 植株的生物量比}

各样地对照枝之间和压枝克隆苗之间叶与植株 的生物量比、叶柄与植株的生物量比、茎与植株的生 物量比差异均不显著 $(p>0.05)$; 对照枝与压枝克隆 苗之间叶与植株的生物量比、叶柄与植株的生物量 比、茎与植株的生物量比差异均极显著 $(p<0.01)$, 对照枝的叶生物量比、叶柄生物量比大于压枝克隆 苗的叶生物量比、叶柄生物量比, 而对照枝的茎生物 量比小于压枝克隆苗的茎生物量比(图 4, 表 1)。

\section{3 讨 论}

黄牛奶树的枝既是营养器官, 也是繁殖器官, 在 其生活史过程中起着重要作用 (张运春等, 2001)。 枝条的性别分化一方面受其自身遗传特性的控制, 另一方面也受环境条件的制约 (王仁忠, 2001)。黄 牛奶树是一种小乔木, 位于常绿阔叶林乔木层的中 下部。在温暖湿润且郁蔽度较大的常绿阔叶林下, 黄牛奶树上部枝条接受较多的光照, 下部枝条接受 光照较少且在湿度较大的环境下极易生出气生根。 植物构件的结构与功能是相适应的, 黄牛奶树上部 枝和下部枝的差异一方面是乔木下部枝自疏的表现 （Fisher \& Honda, 1977; Harper，1985; 黎云祥等, 1998 ), 另一方面也可能是黄牛奶树在自然条件下乔 

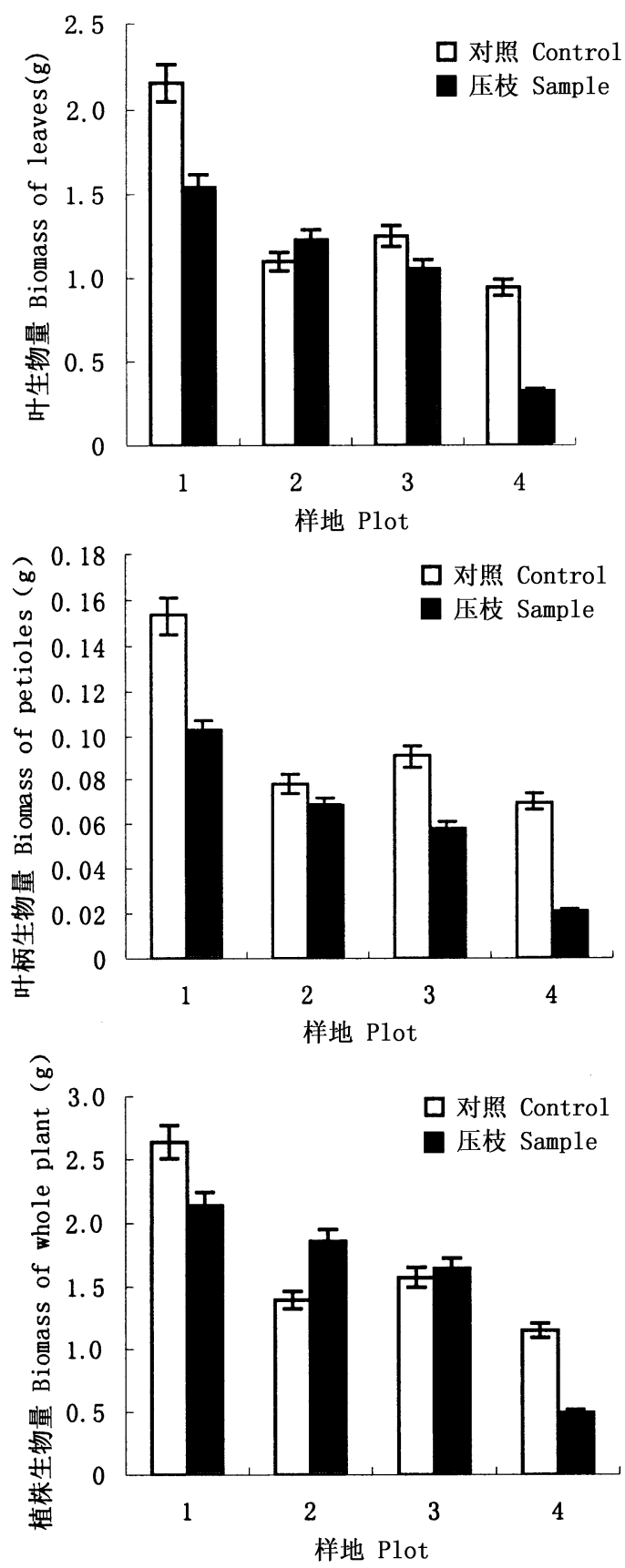

图 3 植株的生物量特征

Fig. 3 Biomass of clonal plant Symplocos laurina

木克隆繁殖的一种特殊适应形式。

构件是组成个体的基本单元, 不同的构件在不 同层次上代表生物, 具有不可替代性, 从构件水平上 对种群进行研究, 可以在个体水平以下了解植物对 环境的反应( White, 1979)。不同生境下同种克隆植 物或不同的克隆植物生殖枝和营养枝在数量、形态 和生理等方面都存在其特有的表现形式(王仁忠, 2001; 黄䩀等, 2004; 郭力华等, 2004)。在自然环境
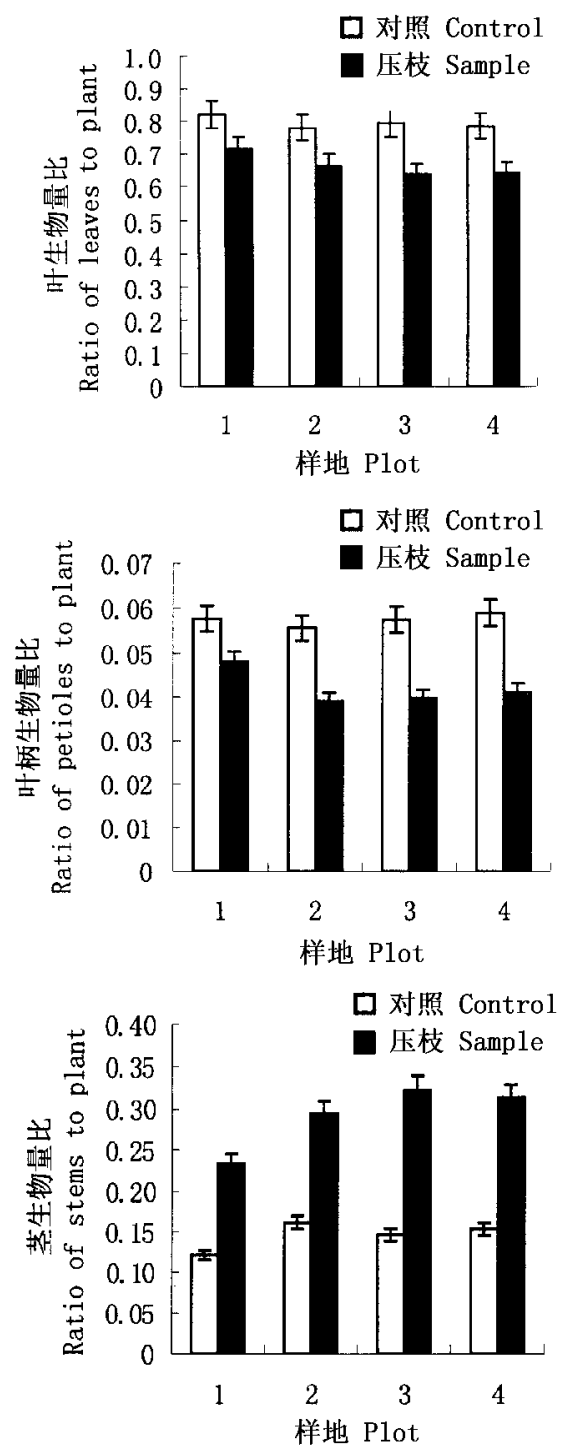

图 4 植株构件的生物量比 Fig.4 Ratio of plant biomass

中,植物所必需的资源 (如光照、热量、水分和养分 等) 呈异质性分布, 并且在很小的尺度上也能观察到 （董鸣, 1996a，1996b）。植物为了获得其生存、生长 和繁殖所需的资源, 就会对这种异质性作出反应 ( de Kroon \& Hutchings, 1995)。对照枝 (即营养枝) 作为 大乔木的基本构件, 对环境的反应能够体现整个乔 木植株对周围环境的反应情况。本实验各样地对照 枝之间的年萌发次数差异不显著, 而各样地压枝形 成的克隆苗之间的年萌发次数有显著差异, 表明黄 牛奶树的营养枝作为高大植株的一部分, 其年萌发 次数对环境的变化不敏感,而刚形成的克隆苗虽然 尚与母株相连, 但仍受环境的较大影响 (Alpert, 1996; D’ Hertefeldt \& Jónsdóttir, 1999; 董鸣, 1996a, 1996b; 王昱生和李景信, 1992; 王昱生和盖晓春, 
1995)。着地形成克隆苗的枝与对照枝相比, 在年萌 发次数上差异明显, 后者显著多于前者 $(p<0.01)$ 。 枝形成苗后角色发生改变, 由普通的侧枝变为一棵 小苗的主干从而具有顶端优势 (潘瑞炽和董愚得, 2001 ), 因此年萌发次数增加。另外, 根可以合成多 种氨基酸、植物碱和细胞分裂素等供应地上部分, 这 些物质能促进植物的生长代谢 (潘瑞炽和董愚得, 2001 ), 因此生根也可能是使克隆苗对环境敏感和刺 激压枝克隆苗再次萌发的原因。

叶的形成与叶原基形成有关, 其数量在芽时已 确定(陆时万等, 1982)。对照枝一年内基本上无二 次萌发现象, 因而叶量变化不大; 而压枝克隆苗一年 内有几次萌发且可塑性较大, 故其叶量也有明显变 化 ( $p<0.01$ ), 在各样地内均表现出较大的可塑性, 由于多次萌发压枝克隆苗的叶量多于对照枝。一般 乔木每叶达到的最大面积随株龄的增长有减小的趋 势(黎云祥等, 1997; Alexandra et al .,2004) 并且其大 小受多种因素影响 ( Pearsall \& Hanby, 1926; Ashby, 1948; Dale, 1982; Goodwin \& Erwee, 1983; Terry et al ., 1983 ), 克隆苗的单叶面积表现与其它乔木叶面积的 表现不同, 这说明克隆苗虽然已成为一个新的个体, 但由于与母体还有一定的联系, 某些方面还受其影 响 ( Alpert \& Mooney, 1986; Schmid, 1987; Mogie \& Hutchings, 1990; Pitelka, 1985; Alpert, 1996; D'Hertefeldt \& Jónsdóttir, 1999; 董鸣, 1996a, 1996b), 从而采取了 一种特有的适应方式。绿色叶片系统是植物同化系 统的主要构件, 为植物进行光合作用制造有机养料 （潘瑞炽和董愚得, 2001), 总叶面积大小反映植株获 取光能的能力, 单叶面积大小及叶量多少是植株增 加总叶面积所采取的具体方式。树木的枝条除具输 导作用外 (潘瑞炽和董愚得, 2001), 还将叶展到适宜 的空间形成一个合理的光能截取树冠体系(黎云祥 和刘玉成, 1996; Day et al.,2002; Thomas \& Winner, 2002 ), 不同的植物根据环境的不同采取不同的方式 来获取光能 (Seiwa, 1999a, 1999b; Gill et al, 1998; Augspurger \& Bartlett, 2003)。从克隆苗与对照枝的 光合构件特征看, 枝分化成克隆苗后在对截取光能 方面采取了不同的策略, 对照枝作为进行光合作用 的主要构件, 主要通过增加单叶面积占据更大的垂 直空间来增大总叶面积以截取更多阳光; 而压枝形 成的克隆苗作为一个新的生命体, 主要通过增加叶 量占据更大的水平空间来增大总叶面积以截取更多 阳光。但在相同生境下对照枝与压枝克隆苗达到的 总叶面积却无显著差异。克隆苗之所以采取以上的
方式可能是母株生根共同作用的结果。

分析植物各器官的生物量的比值有助于我们了 解植物的光合作用潜力以及生长特征 (周世强和黄 金燕, 1997)。黄牛奶树的叶生物量、叶柄生物量及 植株的总生物量由于各样地异质性的存在具较大的 可塑性, 在各样地间有显著差异, 这和草本克隆植物 是一致的 (Alpert, 1996; 王昱生和盖晓春, 1995; 杨持 和杨理, 1997; 陈劲松等, 2003)。压枝对叶生物量、 叶柄生物量及植株的总生物量无显著影响。茎的生 物量受生境影响不大, 在草本克隆植物中也得到类 似的结果 (单保庆等, 2000), 但压枝对其影响显著, 压枝后茎生物量显著增大。从各构件的生物量特征 看, 生境对对照枝与压枝克隆苗生物量分配影响不 大, 压枝对其影响较大, 对照枝的生物量主要分配在 叶和叶柄等光合构件上, 而压枝克隆苗的生物量主 要分配在茎上。结构与功能是相适应的 (陆时万等, 1982), 对照枝的主要功能是支持叶组成有效的光合 系统而压枝克隆苗是要长成乔木的主干, 生物量的 分配说明枝在分化后向不同的方向发展。

从上述对黄牛奶树各构件的分析可以看出: 黄 牛奶树的枝担负着支撑叶进行光合作用和克隆苗繁 殖两种功能。同样的枝在功能转变过程中其年萌发 次数、光合构件及生物量分配方面都有了一定的差 异。当黄牛奶树下部的枝着地形成一个新的植株 时, 它就由原来普通的侧枝分化出来, 担负起成长为 一株乔木的责任。黄牛奶树枝的功能发生变化后形 态方面有了相应的变化, 可能是功能变化后内源激 素合成和分配发生变化的结果, 尤其生根的影响, 但 这有待于进一步研究。

\section{参 考 文 献}

Alexandra R, Michele HN, John JE (2004). Developmental and physiological correlates of leaf size in Hyeronima alchorneoides (Euphorbiaceae). American Journal of Botany, 91, 582-596. Alpert P, Mooney HA (1986). Resource sharing among ramets in the clonal herb, Fragaria chiloensis. Oecologia, 70,227-233. Alpert P (1996). Nutrient sharing natural clonal fragments of Fragaria chiloensis. Journal of Ecology, 84, $395-406$.

Ashby E (1948). An essay on leaf shape. New Phytologist, 47, $153-176$.

Augspurger CK, Bartlett EA (2003). Leaf phenology of juvenile vs. adult trees in a temperate deciduous forest. Tree Physiology, 23, $517-525$.

Cain ML (1990). Models of clonal growth in Solidago altissima. Journal of Ecology, 78,27 - 46 .

Chen JS (陈劲松), Dong M (董鸣), Yu D (于丹) (2003). The 
characteristics of stoloniferous herb Fragaria vesca L. ramet population and their variation along an altitudinal gradient in the eastern edge of the Qing-Zang Plateau in China. Acta Ecologica Sini$c a$ (生态学报), 23,429-435. (in Chinese with English abstract)

Chen S (陈尚), Li ZZ (李自珍), Wang G (王刚) (1997). Advances in researches of growth form of the clonal plant. Chinese Journal of Ecology (生态学杂志), 16(4),59-63. (in Chinese with English abstract)

Chen CD (陈昌笃) (2000). The Dujiangyan-Pivot sector of assemblage, differentiation and maintenance of biodiversity in northern part of Hengduan Mountain. Acta Ecologica Sinica (生态学报), 20, 28 - 34. (in Chinese with English abstract)

Dale JE (1982) . Environmental effects on leaf growth. In: Dale JE ed. The Growth of Leaves. Arnold, London, 31-41.

Day ME, Greenwood MS, Diaz-Sala C (2002) . Age- and size-related trends in woody plant shoot development: regulatory pathways and evidence for genetic control. Tree Physiology, 22, 507 513 .

D’Hertefeldt T, Jónsdóttir IS (1999) . Extensive physiological integration in intact clonal systems of Carex arenaria. Journal of $E$ cology, 87, 258-264.

de Kroon H, Schieving F (1991). Resource allocation patterns as a function of clonal morphology: a general model applied to a foraging clonal plant. Journal of Ecology, 79, 519-530.

de Kroon H, Hutchings MJ (1995). Morphological plasticity in clonal plants: the foraging concept reconsidered. Journal of $E$ cology, 83,143-152.

Dong M (董鸣) (1996a). Clonal growth in plants in relation to resource heterogeneity: foraging behavior. Acta Botanica Sinica (植 物学报), 38,828-835. (in Chinese with English abstract)

Dong M (董鸣) (1996b). Plant clonal growth in heterogeneous habitats: risk-spreading. Acta Phytoecologica Sinica (植物生态 学报), 20,543-548. (in Chinese with English abstract)

Editor Committee for Flora of Sichuan(四川植物志编辑委员会) (1981). Flora of Sichuan (Vol. 1) (四川植物志(第一卷)). Sichuan People's Press, Chengdu. (in Chinese)

Editor Committee of the Chinese Academy of Sciences for Flora of China(中国科学院中国植物志编辑委员会) (1987). Flora of China (Vol. 16, Section 2) (中国植物志 (第十六卷第二 分册)). Science Press, Beijing. (in Chinese)

Fisher JB, Honda H (1977) . Computer simulation of branching pattern and geometry in Terminalia (Combretaceae), a tropical tree. Botanical Gazette, 138,377-384 .

Gill DS, Amthor JS, Bormann RH (1998). Leaf phenology, photosynthesis, and the persistence of saplings and shrubs in a mature northern hardwood forest. Tree Physiology, 18, $281-289$.

Goodwin PB, Erwee MG (1983). Hormonal influences on leaf growth. In: Dale JE, Milthorpe FL eds. The Growth and Functioning of Leaves. Cambridge University Press, London, 207 -
Guo LH (郭力华), Wang L (王立), Liu JX (刘金祥), Yang YF (杨允菲) (2004). A study on photosynthetic physiological characters of vegetative and reproductive tillers of Axonopus compressus. Acta Agrestia Sinica (草地学报),2,103-106. (in Chinese with English abstract)

Harper JL (1985) . Modules, Branch, and the Capture of Resources, Population Biology and Evolution of Clonal Organisms. Yale University Press, New Haven, 82 - 94.

He BH(何丙辉), Zhong ZC (钟章成) (2003).Effects of nutrient supply on modular growth of branch population Ginkgo biloba. Journal of Southwest Agricultural University (Natural Science Edition) (西南农业大学学报 (自然科学版) ), 25,475-478. (in Chinese with English abstract)

Huang J(黄瞕), Pei SJ(裴盛基), Zhang MY(张明宇), Mao J(毛 钧), Yang X (杨雪) (2004). Studies on biological characteristics, ecological habit and geographic distribution of Coptis teeta. Acta Botanica Yunnanica (云南植物研究)，26,255-266. (in Chinese with English abstract)

Institute of Botany, Chinese Academy of Sciences (中国科学院植 物研究所) (1974). Iconographia Cormophytorum Sinicorum (Tomus III) (中国高等植物图鉴(第三册)). Science Press , Beijing. (in Chinese)

Jiang GM (蒋高明), Dong M (董鸣) (2000). A comparative study on photosynthesis and water use efficiency between clonal and non-clonal pant species along the Northeast China Transect (NECT). Acta Botanica Sinica (植物学报), 42, 855 - 863 . (in Chinese with English abstract)

Li YX(黎云祥), Chen L(陈利), Du DL(杜道林), Liu YC(刘玉 成) (1998). The fraction ration and leader-bud dynamics of Gordonia acuminata. Acta Ecologica Sinica (生态学报), 18,309314. (in Chinese with English abstract)

Li YX (黎云祥), Liu YC (刘玉成) (1996). The neighborhood modular interference effects of seedlings of Gordonia acuminata. Journal of Southwest China Normal University ( Natural Science Edition) (西南师范大学学报 (自然科学版) ), 21,309-314. (in Chinese with English abstract)

Li YX(黎云祥), Liu YC(刘玉成), Zhong ZC(钟章成) (1997). Quantitative structure and dynamics of leaf populations of Gordonia acuminata on Jinyun Mountain. Acta Phytoecologica Sinica (植物生态学报), 21, 67-76. (in Chinese with English abstract)

Lu SW (陆时万), Xu XS(徐祥生), Shen MJ (沈敏键) (1982). Botany (植物学) 2nd edn. Higher Education Press, Beijing, 153. (in Chinese)

Maillette L (1992). Seasonal model of modular growth in plant. Journal of Ecology, 80,123 - 130 .

Mogie M, Hutchings MJ (1990). Phylogeny, ontogeny and clonal growth in vascular plant. In: van Groenendael J, de Kroon $\mathrm{H}$ eds. Clonal Growth in Plants: Regulation and Function. SPB Academic, The Hague, 3-22.

Pan RC(潘瑞炽), Dong YD(董愚得), (2001). Plant Physiology 
(植物生理学)3rd edn. Higher Education Press, Beijing, 256 259. (in Chinese)

Pearsall WH, Hanby AM (1926). Growth studies. V. Factors affecting the development and form of leaves. Annals of Botany, $40,85-103$.

Pitelka LF (1985). Physiology and integration of ramets in clonal plants. In: Jackson JBC, Buss LW, Cook RE eds. Population Biology and Evolution of Clonal Organisms. Yale University Press, London, 399 - 436.

Schmid B (1987). Clonal integration and population structure in perennials: effects of severing rhizome connections. Ecology, $68,2016-2022$.

Seiwa K (1999a). Changes in leaf phenology are dependent on tree height in Acer mono, a deciduous broad-leaved tree. Annals of Botany, 83,355 - 361 .

Seiwa K (1999b) . Ontogenetic changes in leaf phenology of Ulmus davidiana var. japonica, a deciduous broad-leaved tree. Tree Physiology, 19,793 - 797 .

Shan BQ(单保庆), Du GZ (杜国祯), Liu ZH (刘振恒) (2000). Clonal growth of Ligularia virgaurea: morphological responses to nutritional variation. Acta Phytoecologica Sinica (植物生态学 报 ), 24,45-51. (in Chinese with English abstract)

Terry N, Waldron LJ, Taylor SE (1983) . Environmental influences on leaf expansion. In: Dale JE, Milthorpe FL eds. The Growth and Functioning of Leaves. Cambridge University Press, Cambridge. $179-205$.

Thomas SC, Winner WE (2002). Photosynthetic differences between saplings and adult trees: an integration of field results by metaanalysis. Tree Physiology, 22,117-127.

Wang YS (王昱生), Li JX (李景信) (1992). Study on growth pattern of Aneurolepidium chinense clonal population. Acta Phy- toecologica et Geobotanica Sinica (植物生态学与地植物学学 报), 16,224-241. (in Chinese with English abstract)

Wang YS (王昱生), Gai XC (盖晓春) (1995). Foraging growth patterns and resource allocation of clonal Leymus chinensis population in the sungnen steppe. Acta Phytoecologica Sinica (植物生 态学报), 19, 293-301. (in Chinese with English abstract)

Wang RZ (王仁忠) (2001). Comparative study on clonal and sexual reproductive traits of Leymus chinensis populations in different habitats. Chinese Journal of Applied Ecology (应用生态学报), 12, 379 - 383. (in Chinese with English abstract)

White J (1979). The plant as a metapopulation. Annual Review of Ecology and Systematics, 10,109-145.

Yang C (杨持), Yang L (杨理) (1997). Influence of light intensity on differentiation and growth of Leymus chinensis clone. Chinese Journal of Applied Ecology (应用生态学报), 8, 83-87. (in Chinese with English abstract)

Zhang WY(张炜银), Wang BS (王伯荪), Li MG (李鸣光), Zan QJ(处启杰), Wang YJ(王勇军) (2002). The branching pattern and biomass of Mikania micrantha shoot modules in Acacia confusa community and Miscanthus sinensis community. Acta Phytoecologica Sinica (植物生态学报)，26, 346 - 350. (in Chinese with English abstract)

Zhang YC (张运春), Su ZX (苏智先), Gao XM (高贤明) (2001). Character and research of clonal plant. Journal of Sichuan Teachers College (Natural Science Edition) (四川师范 学院学报 (自然科学版)), 22,338 - 343. (in Chinese with English abstract)

Zhou SX(周世强), Huang JY (黄金燕) (1997). A study on the clonal population biomass of young Bashania fangiana after natural regeneration. Journal of Bamboo Research (竹子研究汇刊), 16(2), 33 - 39. (in Chinese with English abstract)

责任编委: 董 鸣 责任编辑: 姜联合 